\title{
OPEN Effect of arbuscular mycorrhizal fungi on the physiological functioning of maize under zinc-deficient soils
}

\author{
Abdul Saboor ${ }^{1}$, Muhammad Arif Ali ${ }^{1 凶}$, Subhan Danish ${ }^{1,3 凶}$, Niaz Ahmed $^{1}$, Shah Fahad ${ }^{2}$, \\ Rahul Datta ${ }^{3}$, Mohammad Javed Ansari ${ }^{4}$, Omaima Nasif ${ }^{5}$, Muhammad Habib ur Rahman ${ }^{6}$ \& \\ Bernard R. Glick ${ }^{7}$
}

Zinc (Zn) deficiency can severely inhibit plant growth, yield, and enzymatic activities. $Z n$ plays a vital role in various enzymatic activities in plants. Arbuscular mycorrhizal fungi (AMF) play a crucial role in improving the plant's $\mathrm{Zn}$ nutrition and mitigating $\mathrm{Zn}$ stress effects on plants. The current study was conducted to compare the response of inoculated and non-inoculated maize ( $\mathrm{YH}$ 1898) in the presence of different levels of zinc under greenhouse conditions under a $\mathrm{Zn}$ deficient condition. There were two mycorrhizal levels (i.e., $M+$ with mycorrhizae, $M$ - without mycorrhizae) and five $\mathrm{Zn}$ levels (i.e., $0,1.5$, 3,6 , and $12 \mathrm{mg} \mathrm{kg}^{-1}$, with three replicates following completely randomized design. At the vegetative stage (before tillering), biochemical, physiological, and agronomic attributes were measured. The results showed that maize plants previously inoculated with AMF had higher gaseous exchange traits, i.e., a higher stomatal conductance rate, favoring an increased photosynthetic rate. Improvement in antioxidant enzyme activity was also observed in inoculated compared to non-inoculated maize plants. Moreover, AMF inoculation also played a beneficial role in nutrients availability and its uptake by plants. Higher Zn12 (12 mg Zn kg-1 soil) treatment accumulated a higher Zn concentration in soil, root, and shoot in AMF-inoculated than in non-inoculated maize plants. These results are consistent with mycorrhizal symbiosis beneficial role for maize physiological functioning in $\mathrm{Zn}$ deficient soil conditions. Additionally, AMF inoculation mitigated the stress conditions and assisted nutrient uptake by maize.

Zinc $(\mathrm{Zn})$ deficiency is widespread in arid and semi-arid regions, especially in alkaline calcareous soils, because of a high $\mathrm{Zn}$ fixation rate and $\mathrm{Zn}$ low mobility in such soil conditions ${ }^{1,2}$. Although a sufficient amount of $\mathrm{Zn}$ is present in the soil, only a small quantity of $\mathrm{Zn}$ is available for plant uptake. Zinc is mainly immobile in the soil as it is highly adsorbed to the surface of soil colloids ${ }^{3}$. Zinc deficiency is further aggravated by high soil pH, high soil Ca contents, mono-cropping, intensive agriculture and over the use of fertilizers. For instance, Rafique et al. ${ }^{4}$ reported that $80 \%$ of Pakistan's rainfed soil area is deficient in $\mathrm{Zn}$ due to high soil pH. Zinc deficiency of $\mathrm{Zn}$ in the surface layer of soils is widespread and its deficiency in plant tissues severely impacts their growth and reduces crop yields. Reduced plant concentrations of Zn stimulates reactive oxygen species (ROS) in plant tissues ${ }^{5}$. These ROS disrupt cell membranes and hinder normal cell functioning ${ }^{6}$. The ROS includes hydrogen peroxide and superoxide radicals, which cause extensive damage to plant tissue. On the other hand, $\mathrm{Zn}$ is involved in the gene expression, detoxification of ROS and activation of antioxidant enzyme production, including superoxide dismutase (SOD), peroxidase $(\mathrm{PO})$ and catalase $(\mathrm{CAT})^{7}$.

\footnotetext{
${ }^{1}$ Department of Soil Science, Faculty of Agricultural Sciences and Technology, Bahauddin Zakariya University, Multan 60800, Pakistan. '2Department of Agronomy, The University of Haripur, Haripur 22620, Pakistan. ${ }^{3}$ Department of Geology and Pedology, Faculty of Forestry and Wood Technology, Mendel University in Brno, Zemedelska1, 61300 Brno, Czech Republic. "Department of Botany, Hindu College Moradabad (Mahatma Jyotiba Phule Rohilkhand University Bareilly), Bareilly 244001, India. ${ }^{5}$ Department of Physiology, College of Medicine and King Khalid University Hospital, King Saud University, Medical City, PO Box-2925, Riyadh 11461, Saudi Arabia. 'Department of Agronomy, MNS-University of Agriculture-Multan, Multan 60000, Pakistan. ${ }^{7}$ Department of Biology, University of Waterloo, Waterloo, ON N2L 3G1, Canada. ${ }^{\square}$ email: arif1056@ bzu.edu.pk; sd96850@gmail.com
} 
Most scientists suggest organic amendments, i.e., biochar ${ }^{3,8-14}$, biofertilizer ${ }^{15-28}$, humic substances, and organic matter ${ }^{29-31}$, to overcome the problem of abiotic and biotic stresses in crops. Arbuscular mycorrhizal fungi are well-known biofertilizers that protect host plants from biotic and abiotic stress by improving plant nutrition, especially $\mathrm{P}$ and $\mathrm{Zn}^{8,9}$. Extraradical hyphae of fungi explore the rhizosphere and bulk soil and enhance the uptake of nutrients with a low mobility rate like $\mathrm{P}, \mathrm{Zn}$ and $\mathrm{Cu}$. Most of the plants are colonized through AMF by Following two nutrients pathways. 1). Epidermis of roots, which is a direct pathway of uptake. 2). The formation of a fungal structure that designed mycorrhizal pathway uptake ${ }^{10}$.

Inoculation of mycorrhiza played an imperative role in the improvement of the chlorophyll contents of the plant. It also improved carotenoids contents end modified the synthesis of antioxidant enzymes, which regulates the metabolic activities under stress conditions ${ }^{11}$. Colonization of mycorrhiza increases the area under the rhizosphere through better branching of plant roots. Improvement in the branch also increases the uptake of water and nutrients, due to which growth and productivity of crops are increased ${ }^{12-14}$. Some studies have reported that mycorrhizal infection was sensitive to external $\mathrm{P}$ application, and thus, it affected the availability of other nutrients ${ }^{15,16}$. However, it was also reported that mycorrhizal fungi increased the uptake of $\mathrm{Cu}$ and contributed a $62 \%$ increase in $\mathrm{Cu}$ uptake irrespective of external $\mathrm{P}$ application ${ }^{17}$. Similarly, studies have highlighted the mycorrhizal fungi effect on $\mathrm{Zn}$ nutrition ${ }^{7,18}$. Therefore, instead of using inorganic sources for mitigating $\mathrm{Zn}$ deficiency, the use of mycorrhizal fungi as a bio-fertilizer may be an intriguing way of addressing Zn deficiency.

Subramanian et al. ${ }^{7}$ reported that mycorrhizal fungi trigger antioxidants that enable plants to survive in low $\mathrm{Zn}$ growing medium like $\mathrm{Zn}$ deficient soil. Studies have shown that mycorrhiza inoculated plants possess a high concentration of antioxidant enzymes above and below ground parts ${ }^{19}$. The AM fungi can increase the plant sugar and leaf proline contents and maintain plant cells' osmotic potential, protecting the plant's enzymatic activities. AM fungi also increased the acid phosphatase activity in roots, leading to the improved nutritional value of inoculated plants ${ }^{20}$. Moreover, AM fungi also increased $\mathrm{Zn}$ and $\mathrm{P}$ concentrations in plant tissues, thereby positively affecting plant physiological processes such as photosynthesis, respiration, and stomatal conductance. Zinc is involved in chlorophyll synthesis; therefore, improved Zn nutrition in mycorrhizal plants stimulates chlorophyll synthesis ${ }^{21}$. So far, scientists have worked on AMF and Zn application solely under Zn deficiency to improve growth and yield in maize. However, the current study will cover the knowledge gap with the novel aspect of AMF and Zn application rates influence on antioxidants and physiological attributes of maize under $\mathrm{Zn}$ deficient. That's why the current study was conducted to explore the efficacy of AMF for better uptake of $\mathrm{Zn}$ in maize in $\mathrm{Zn}$ deficient soil. It is hypothesized that AMF has the potential to mitigate Zn deficiency by unbalanced $\mathrm{Zn}$ application in maize.

\section{Materials and methods}

Experimental soil and location. The soil from the experimental site was aridisol, clay loam in texture, alkaline in $\mathrm{pH}(8.3)$, and contained low organic matter $(0.58 \%)^{22}$. The available phosphorus level was $6.4 \mathrm{mg} / \mathrm{kg}$ extracted with $\mathrm{NaHCO}_{3}{ }^{23}$, the potassium level was $225 \mathrm{mg} / \mathrm{kg}^{24}$, and the $\mathrm{Zn}$ level was $0.45 \mathrm{mg} / \mathrm{kg}^{25}$. The soil was taken from field latitude 29.92 and longitude 71.52 .

Experimental site and design. A pot experiment was conducted in loamy soil to evaluate Zn deficiency effects on a maize crop's physiological functioning at the research area of the Department of Soil Science Bahauddin Zakaria University, Multan Pakistan. The study was arranged according to a completely randomized design (CRD).

Pot preparation and treatments. For this purpose, clay pots with $10 \mathrm{~kg}$ soil were filled with a mixture of soil and sand in a 4:1 ratio; the purpose of adding sand is to provide a mixture from which roots can be easily extracted. Plants were grown for a total period of 45 days after sowing. The treatments were two mycorrhizal levels (i.e., $\mathrm{M}^{+}$with mycorrhizae, $\mathrm{M}^{-}$without mycorrhizae) and five $\mathrm{Zn}$ levels (i.e., 0, 1.5, 3, 6, and $12 \mathrm{mg} / \mathrm{kg}$ ), with the entire experiment being repeated three times. The required quantity of $\mathrm{Zn}$ was applied using analytical grade zinc heptahydrate $\left(\mathrm{ZnSO}_{4} \cdot 7 \mathrm{H}_{2} \mathrm{O}\right)$.

Fertilizer application and AMF inoculation. Nitrogen fertilizer (227.24 $\left.\mathrm{kg} \mathrm{ha}^{-1}\right)$ was applied in three separate aliquots. Half of $\mathrm{P}\left(71.63 \mathrm{~kg} \mathrm{ha}^{-1}\right)$ and full recommended dose of $\mathrm{K}\left(91.93 \mathrm{~kg} \mathrm{ha}^{-1}\right)$ were applied as a basal dose at the time of sowing. The AM inoculum containing a consortium of Glomus species, i.e., mycorrhizal inoculum Clonex ${ }^{\oplus}$ (Root Maximizer; 5711 Enterprise Drive, Lansing, MI, USA) having 158 propagules gram ${ }^{-1}$ was applied at $25 \mathrm{~g}$ inoculum per pot. Thiophanate methyl fungicide was applied to the control treatments at $50 \mathrm{mg} \mathrm{kg}^{-1}$ fortnight ${ }^{-1}$ pot $^{-1}$ to control the root mycorrhizal colonization.

Seeds sowing and irrigation. Five maize seeds (YH $1898 \mathrm{cv}$.) were sown per pot. After 20 days of growth, only 2 healthy plants per pot were maintained. The selection was made based on visual observations. The moisture content in each pot was maintained at $60 \%$ of the total WHC.

Harvesting. At the vegetative stage (before tillering), biochemical, physiological, and agronomic attributes were measured.

Tissue and soil analysis. Fresh plant leaves and roots were excised, rinsed with water and oven-dried at $72^{\circ} \mathrm{C}$ for $24 \mathrm{~h}$. Plant leaf and fresh root weights and dried weights were recorded. Total $\mathrm{N}$ was determined by the calorimetric method ${ }^{26}$. Phosphorus was analyzed using the malachite green method ${ }^{27}$. Potassium was determined 
by flame photometer ${ }^{28}$. Pre- and post-treatment soil samples were collected to observe the nutrient status of the soil. Soil zinc was extracted by the DTPA extraction method and analyzed using an Atomic Absorption Spectrophotometer $(\mathrm{AAS})^{25}$. The soil $\mathrm{pH}^{29}$ and $\mathrm{EC}^{30}$ were determined in soil water suspensions of 1:5 (soil:water) ratios using $\mathrm{pH}$ and EC meters.

Physiological parameter. The stomatal conductance, photosynthetic rate, and transpiration rate were measured using an IRGA (infrared gas analyzer). All physiological parameters were measured between 9 and $11 \mathrm{AM}$ to avoid low humidity and high external temperature ${ }^{31}$.

Chlorophyll contents. Chlorophyll contents were determined by the procedure of Arnon ${ }^{32}$. The intensity of green color extract from fresh plant leaves was measured at 645 and $663 \mathrm{~nm}^{32}$.

$$
\begin{gathered}
\text { Chlorophyll a }\left(\mathrm{mg} \mathrm{g}^{-1} \text { Fresh Weight }\right)=\frac{12.7(\text { value at } 663 \mathrm{~nm})-2.69(\text { value at } 645 \mathrm{~nm})}{1000(\mathrm{~W})} \\
\text { Chlorophyll b }\left(\mathrm{mg} \mathrm{g}^{-1} \text { Fresh Weight }\right)=\frac{22.9(\text { value at } 645 \mathrm{~nm})-4.68(\text { value at } 663 \mathrm{~nm})}{1000(\mathrm{~W})} \\
\text { Total Chlorophyll }\left(\mathrm{mg} \mathrm{g}^{-1} \text { Fresh Weight }\right)=\frac{20.2(\text { value at } 645 \mathrm{~nm})-8.02(\text { value at } 663 \mathrm{~nm})}{1000(\mathrm{~W})}
\end{gathered}
$$

${ }^{\star} \mathrm{W}=$ Fresh weight of leaves.

Enzymatic analysis. Determination of antioxidant enzymes was done by collecting fresh leaves, which were immediately kept in liquid nitrogen. Later, $1 \mathrm{~g}$ of sample was ground and completely homogenized in $50 \mathrm{mM}$ phosphate.

Superoxide dismutase. This enzyme was measured by the method of Giannopolitis and Ries ${ }^{33}$. A mixture of $1 \mathrm{~mL}$ nitroblue tetrazolium (NBT) $(50 \mathrm{mM}), 500 \mu \mathrm{L}$ ethylenediaminetetraacetic acid (EDTA) $(75 \mathrm{mM}), 1 \mathrm{~mL}$ riboflavin $(1.3 \mu \mathrm{M}), 950 \mu \mathrm{L}$ sodium phosphate buffer $(50 \mathrm{mM})$, and $0.5-\mathrm{mL}$ methionine $(13 \mathrm{mM})$ was prepared. A $50 \mu \mathrm{L}$ sample extract was added, and the mixture was placed under fluorescent light for $5 \mathrm{~min}$. The absorbance of the resultant solution was measured at $560 \mathrm{~nm}$. The SOD activity was measured in IU min $\mathrm{mgg}^{-1}$ protein.

Catalase. A mixture of $0.9 \mathrm{~mL} \mathrm{H}_{2} \mathrm{O}_{2}(5.9 \mathrm{mM})$ in $2 \mathrm{~mL}$ phosphate buffer $(50 \mathrm{mM})$. was used to measure the catalase activity (CAT). $0.1 \mathrm{~mL}$ of an enzyme extract was mixed with the mixture. After $30 \mathrm{~s}$ the absorbance was measured at $240 \mathrm{~nm}$ and monitored continuously for 5 min to measure the disintegration of $\mathrm{H}_{2} \mathrm{O}_{2}$ by CAT activity ${ }^{34}$. The CAT activity was measured in $\mu \mathrm{mol} \mathrm{min} \mathrm{mg}^{-1} \mathrm{mg}^{-1}$ protein.

Peroxidase. $\quad 100 \mu \mathrm{L}$ enzyme extract was added to a solution of $2 \mathrm{~mL}$ sodium phosphate buffer $(50 \mathrm{mM}), 400-\mu \mathrm{L}$ guaiacol $(20 \mathrm{mM})$, and $500 \mu \mathrm{L} \mathrm{H}_{2} \mathrm{O}_{2}(40 \mathrm{mM})$. The absorbance of this mixture was measured at an interval of $20 \mathrm{~s}$ for $5 \mathrm{~min}$. The peroxidase (POD) concentration was calculated by the absorbance change $\mathrm{e}^{34}$. The POD activity was measured in $\mu \mathrm{mol} \mathrm{min}^{-1} \mathrm{mg}^{-1}$ protein.

Total soluble proteins (TSP). The method of Sambrook and Russell ${ }^{35}$ was used to determine the total soluble proteins, and the Bradford ${ }^{36}$ method was used to estimate the TSP. A $200 \mu \mathrm{L}$ of either leaf or root extract was mixed into $780 \mu \mathrm{L}$ DI water and $20 \mu \mathrm{L}$ of Coomassie blue dye. The absorbance of this sample was measured at $595 \mathrm{~nm}$. The TSP was expressed in $\mathrm{mg} \mathrm{mL}^{-1}$.

Mycorrhizal colonization. The fine roots of maize plants were harvested and then washed with $\mathrm{KOH}(10 \%$ $\mathrm{w} / \mathrm{v})^{37}$. The root was then stained with a 0.05 trypan blue solution ${ }^{38}$. The gridline intersects method was used to search for the presence of AM structure in roots.

Statistical analysis. The data was analyzed using two factorial analysis of variance (ANOVA) and treatments were compared using the Least Significant Difference (LSD) test at $p \leq 0.05^{39}$ on Statistical Package Statistix 8.1 (Tallahassee Florida, USA). Correlation and principal component analysis (PCA) were performed using XLSTAT-2014.

Institutional, national, and international guidelines and legislation. Current experiment meets all international, national and/or institutional guidelines for experimental research and field studies on plants (either cultivated or wild), including the collection of plant material.

Relevant permits/permissions/licences. For collection of maize seeds all relevant permits or permissions have been obtained. 


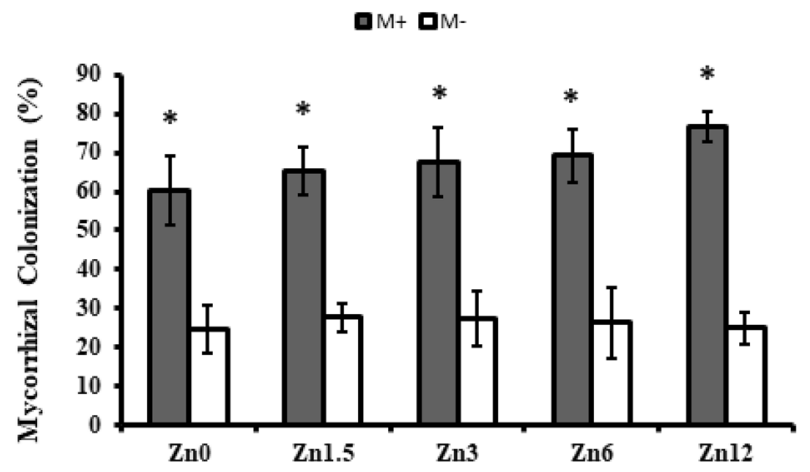

Figure 1. Effect of arbuscular mycorrhizal fungi inoculation on mycorrhizal colonization by maize under zinc deficient soil conditions $\mathrm{Zn}_{0}$ (control), $\mathrm{Zn}_{1.5}\left(1.5 \mathrm{mg} \mathrm{kg}{ }^{-1}\right.$ ), $\mathrm{Zn}_{3}\left(3 \mathrm{mg} \mathrm{kg}{ }^{-1}\right), \mathrm{Zn}_{6}\left(6 \mathrm{mg} \mathrm{kg}{ }^{-1}\right), \mathrm{Zn}_{12}\left(12 \mathrm{mg} \mathrm{kg}^{-1}\right)$, inoculated with AMF (M+grey), un-inoculated (M- white). Error bars represent standard error. Inoculated with $\operatorname{AMF}(\mathrm{M}+$ grey); un-inoculated (M- white).

Ethics approval and consent to participate. We all declare that manuscripts reporting studies do not involve any human participants, human data, or human tissue. So, it is not applicable.

Complies with international, national and/or institutional guidelines. Current experiment meets all international, national and/or institutional guidelines.

\section{Results}

Colonization of mycorrhizal fungi. Data regarding mycorrhizal colonization was measured from the roots of both inoculated and un-inoculated maize plants. A significant $(p \leq 0.05)$ increase in mycorrhizal colonization was observed following inoculation irrespective of zinc levels. The inoculated roots showed colonization of mycorrhiza in the range of $60-76 \%$ whereas, un-inoculated roots had $24-27 \%$ root colonization. Maximum colonization was observed with the treatment of Zn12 as compared to the other treatments (Fig. 1).

Influence of AMF on gaseous exchange traits. The stomatal conductance rate consistently increased with the increment in the zinc fertilization levels. A significant $(p \leq 0.05)$ difference was noticed among inoculated and non-inoculated maize plants. The highest stomatal conductance rate was measured from $\mathrm{Zn} 12$ inoculated with an increase of $12 \%$ compared to the control, whereas its counterpart showed the least stomatal conductance rate with the decrease of $36 \%$ in $\mathrm{M}$ - compared to the control (Fig. 2). Changes to the photosynthetic rate were similar to those observed for the stomatal conductance rate. The $\mathrm{Zn} 12(\mathrm{M}+)$ showed the highest photosynthetic rate with an increase of $35 \%$, while $\mathrm{M}$ - had a $6 \%$ decrease in photosynthetic rate. The remaining inoculated plants also had a higher photosynthetic rate at different zinc levels, showing significant $(p \leq 0.05)$ differences compared to non-inoculated plants. The $M+$ plant with the highest zinc level (Zn12) tested in this study exhibited a higher transpiration rate with a $56 \%$ increase compared to the control ( $\mathrm{Zn} 0)$, while M- plants with $\mathrm{Zn} 12$ treatment exhibited a $77 \%$ decrease in transpiration rate compared to the Zn0 (Fig. 2).

Arbuscular mycorrhizal fungi effect on chlorophyll contents. This study also quantified the change in chlorophyll contents with the varying zinc levels with and without mycorrhizal inoculation; these values tend to increase more with mycorrhizal inoculation. All the chlorophyll contents ( $a, b$, and total) indicated an increase in inoculated $(\mathrm{M}+)$ plants compared to $\mathrm{M}$ - plants. The chlorophyll a content was found to increase by $8 \%$ in $\mathrm{Zn} 12$, although a decrease of up to $10 \%$ was observed in non-inoculated plants. Likewise, the chlorophyll b content increased by $20 \%$ (Zn12) in M + plants and showed a $26 \%$ decrease in non-inoculated plants. Similar results were observed for total chlorophyll contents in that $\mathrm{Zn12}(\mathrm{M}+)$ had a $15 \%$ higher total chlorophyll contents, while $\mathrm{Zn}(\mathrm{M}-)$ resulted in a decline of $6 \%$ (Fig. 3).

Antioxidant enzymes activity. Mycorrhizal inoculated plants showed significantly $(p \leq 0.05)$ higher enzymatic activities than non-inoculated plants at each $\mathrm{Zn}$ level. The highest superoxide dismutase activity was observed in $\mathrm{M}+$ at $\mathrm{Zn} 12$ with an increase of $15 \%$; $\mathrm{M}$ - also showed higher SOD activity by $16 \%$ compared to the control. The catalase activity was also higher with the higher level of zinc fertilization (Zn12). It showed a $19 \%$ increase in $\mathrm{M}+$ and a $20 \%$ increase in $\mathrm{M}$ - compared to their respective controls. Peroxidase also exhibited elevated enzyme activity. It was 30\% higher in $\mathrm{Zn} 12$ with $\mathrm{M}+$ and $68 \%$ higher in $\mathrm{M}$ than their respective controls (Fig. 4). Mycorrhizal inoculation and $\mathrm{Zn}$ fertilization resulted in a significant $(p \leq 0.05)$ increase in maize plants' total soluble protein; these levels increased gradually with the increase in $\mathrm{Zn}$ levels regardless of $\mathrm{M}+$ and M- treatments. The highest TSP was recorded from the $\mathrm{Zn} 12$ in $\mathrm{M}+$ with a $17 \%$ increase whereas, $\mathrm{M}$ - showed a $36 \%$ increase in TSP (Fig. 4). 

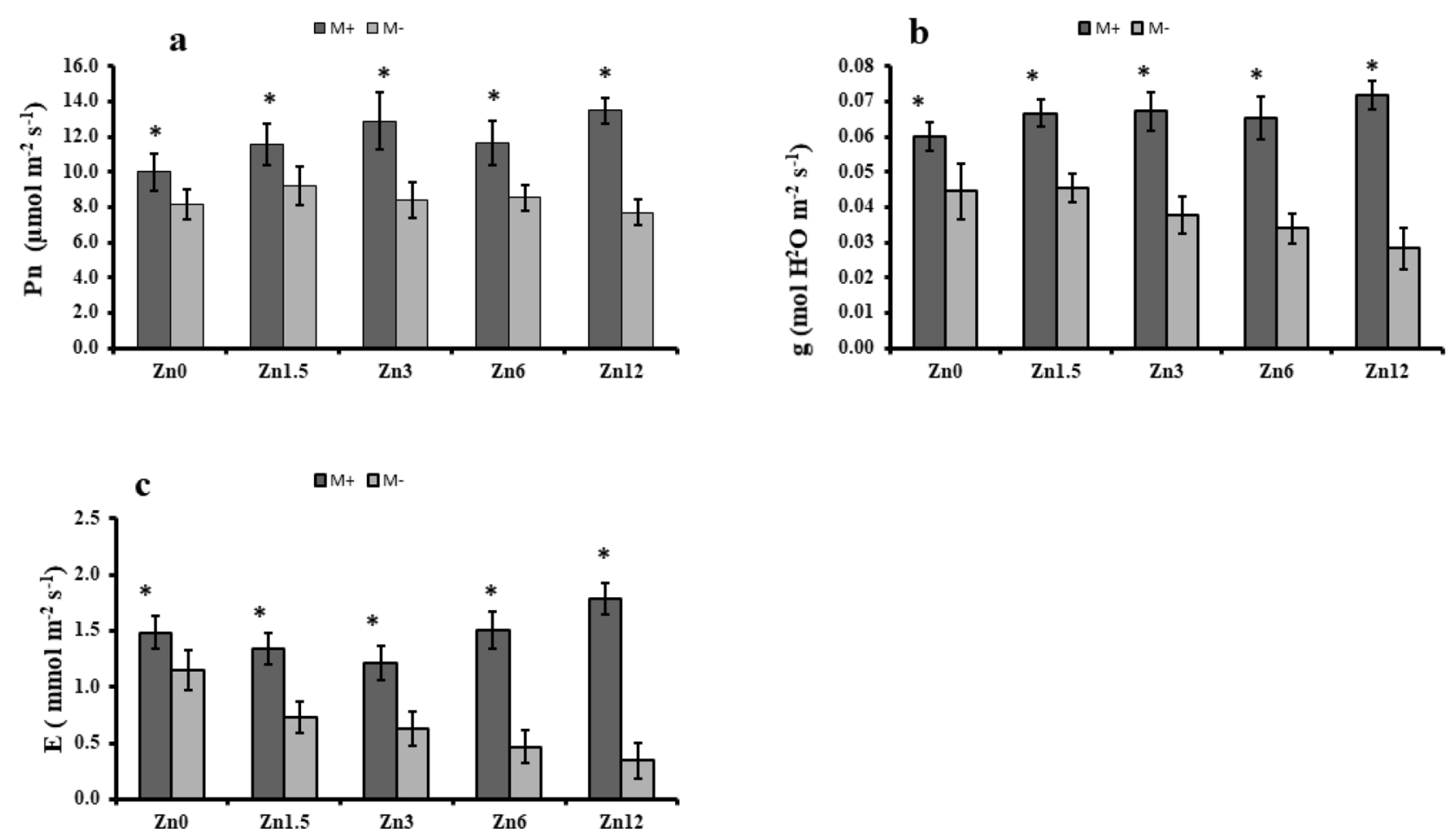

Figure 2. Effect of arbuscular mycorrhizal inoculation on gaseous exchange traits of maize under zinc deficient soil conditions. (a) Photosynthetic rate $\left(\mu \mathrm{mol} \mathrm{m} \mathrm{m}^{-2}\right)$ (b) stomatal conductance $\left(\mathrm{mol} \mathrm{H}_{2} \mathrm{O} \mathrm{m}^{-2} \mathrm{~s}^{-1}\right)$ (c) transpiration rate $\left(\mathrm{mmol} \mathrm{m} \mathrm{s}^{-1}\right)$. $\mathrm{Zn}_{0}$ (control), $\mathrm{Zn}_{1.5}\left(1.5 \mathrm{mg} \mathrm{kg}{ }^{-1}\right), \mathrm{Zn}_{3}\left(3 \mathrm{mg} \mathrm{kg}{ }^{-1}\right), \mathrm{Zn}_{6}\left(6 \mathrm{mg} \mathrm{kg}^{-1}\right), \mathrm{Zn}_{12}$ $\left(12 \mathrm{mg} \mathrm{kg}^{-1}\right)$, inoculated with AMF (M+grey), un-inoculated (M- white). Error bars represent standard error and asterisk $\left(^{\star}\right)$ shows a significant difference $(p \leq 0.05)$ among treatments $(\mathrm{Zn} \times$ AMF interaction).
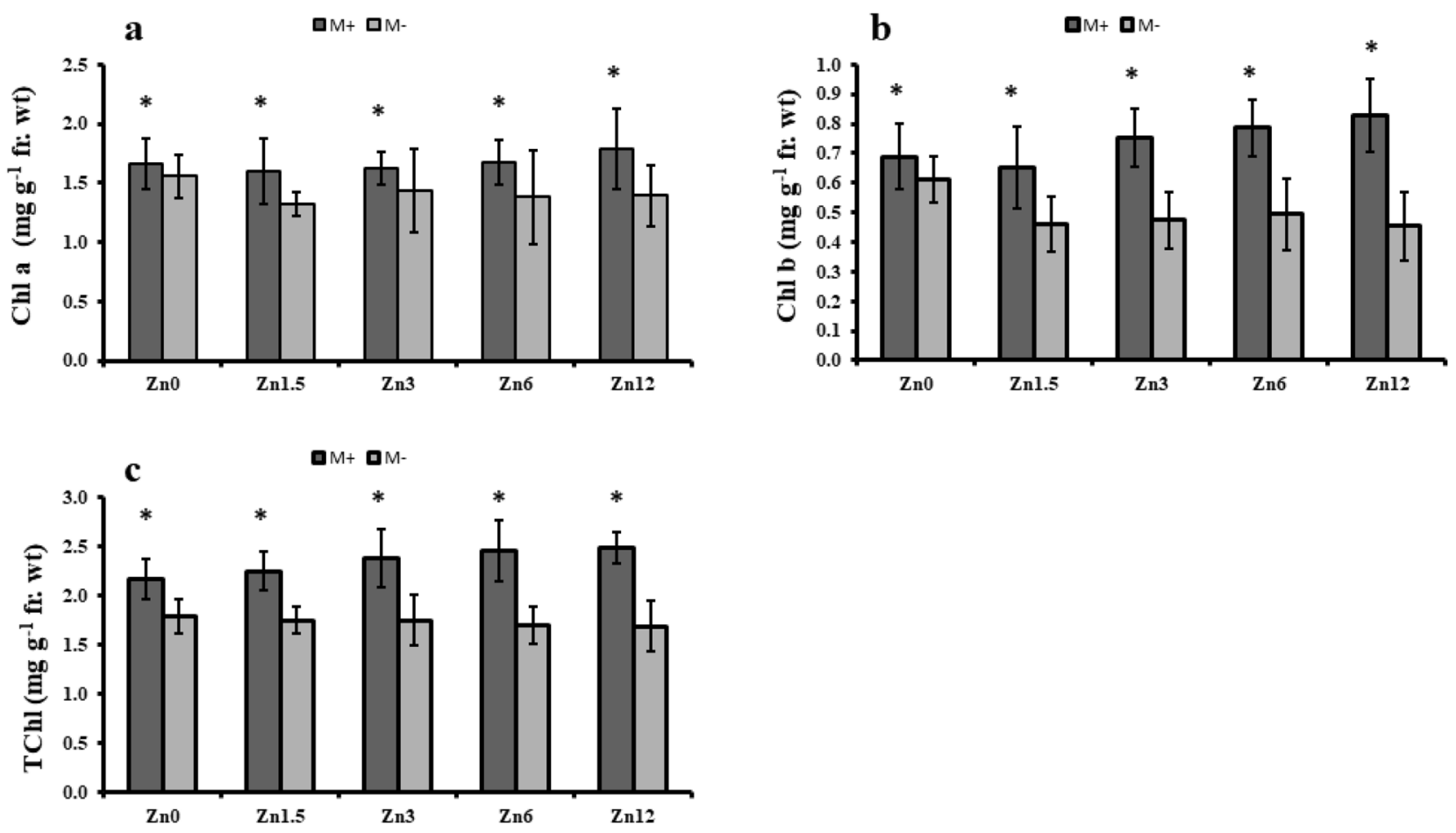

Figure 3. Effect of arbuscular mycorrhizal inoculation on chlorophyll contents of maize under zinc deficient soil conditions. (a) chlorophyll a content $\left(\mathrm{mg} \mathrm{g}^{-1}\right.$ fr. wt) (b) chlorophyll b contents $\left(\mathrm{mg} \mathrm{g}^{-1} \mathrm{fr}\right.$. wt) (c) total chlorophyll contents ( $\mathrm{mg} \mathrm{g}^{-1} \mathrm{fr}$. wt). $\mathrm{Zn}_{0}$ (control), $\mathrm{Zn}_{1.5}\left(1.5 \mathrm{mg} \mathrm{kg}{ }^{-1}\right), \mathrm{Zn}_{3}\left(3 \mathrm{mg} \mathrm{kg}^{-1}\right), \mathrm{Zn}_{6}\left(6 \mathrm{mg} \mathrm{kg}^{-1}\right), \mathrm{Zn}_{12}$ (12 mg kg$\left.{ }^{-1}\right)$, inoculated with AMF (M+grey), un-inoculated (M- white). Error bars represent standard error and asterisk $\left(^{*}\right)$ shows a significant difference $(p \leq 0.05)$ among treatments ( $\mathrm{Zn} \times$ AMF interaction). 

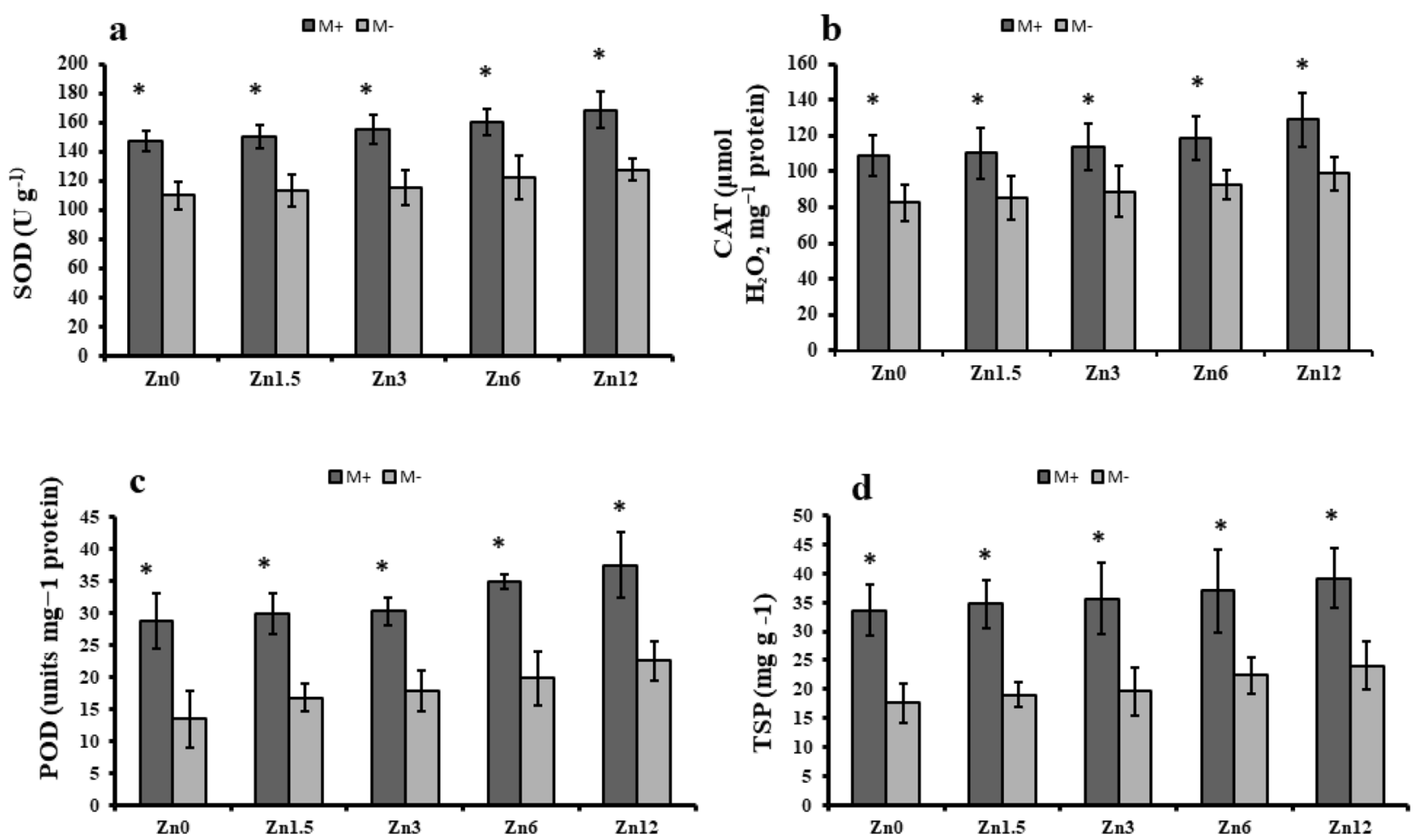

Figure 4. Effect of arbuscular mycorrhizal inoculation on antioxidant enzyme activity of maize under zinc deficient soil conditions. (a) superoxide dismutase $\left(\mathrm{U} \mathrm{g}^{-1}\right)(\mathbf{b})$ catalase $\left(\mu \mathrm{mol} \mathrm{H} \mathrm{O}_{2} \mathrm{mg}^{-1}\right.$ protein) (c) peroxidase ( $\mathrm{U} \mathrm{mg}^{-1}$ protein), (d) total soluble protein $\left(\mathrm{mg} \mathrm{g}^{-1}\right) . \mathrm{Zn}_{0}$ (control), $\mathrm{Zn}_{1.5}\left(1.5 \mathrm{mg} \mathrm{kg}^{-1}\right.$ ), $\mathrm{Zn}_{3}\left(3 \mathrm{mg} \mathrm{kg}^{-1}\right), \mathrm{Zn}_{6}$ $\left(6 \mathrm{mg} \mathrm{kg}^{-1}\right), \mathrm{Zn}_{12}\left(12 \mathrm{mg} \mathrm{kg}^{-1}\right)$, inoculated with AMF (M+grey), un-inoculated (M- white). Error bars represent standard error and asterisk $\left(^{*}\right)$ shows a significant difference $(p \leq 0.05)$ among treatments $(\mathrm{Zn} \times \mathrm{AMF}$ interaction).

Zinc concentration of the soil. The zinc concentration of zinc-deficient soil increased with the addition of zinc with mycorrhizal inoculation. The highest $\mathrm{Zn}$ accumulation from $\mathrm{Zn} 12$, increased by $41 \%$; the lowest $\mathrm{Zn}$ accumulation was measured from $\mathrm{Zn} 0$ (control) with mycorrhizal inoculation. In non-mycorrhizal inoculation, the roots accumulation was also significantly higher under $\mathrm{Zn} 12$ compared to control maize plants. Zn12 also resulted in a higher uptake of the $\mathrm{Zn}$ in shoots, i.e., a 38\% increase in shoots compared to the control. Similarly, with non-inoculated plants, $\mathrm{Zn}$ accumulation was $22 \%$ higher in shoots (Fig. 5).

Phosphorus availability and uptake by maize. In the case of phosphorus availability in soil, Zn12 plants only showed a $2 \%$ increase in phosphorus accumulation in soil, whereas under M- plants exhibited a $6 \%$ increase compared to the control. Moreover, the phosphorus accumulation in shoots was also higher under Mconditions and $\mathrm{Zn12}$, while $\mathrm{M}+$ showed $17 \%$ increase in shoot phosphorus levels. Finally, the higher application of zinc (Zn12) and mycorrhizal inoculation resulted in higher zinc availability in maize soil (Fig. 6).

Correlation analysis. The Pearson correlation coefficients ( $r$ ) for the different physiological and biochemical parameters under zinc-deficient soil conditions are summarized in Table 1. All of the parameters showed a positive correlation. The photosynthetic rate showed a strong positive correlation with stomatal conductance, superoxide dismutase, total soluble protein, total chlorophyll, zinc, and phosphorus in soil. The antioxidant enzymes (SOD, CAT, POD) showed a strong positive correlation with zinc accumulation in the root, shoot and soil, and phosphorus accumulation in soil and maize shoots. Also, these antioxidant enzymes were positively correlated with the maize chlorophyll contents.

Principal component analysis. The interrelationship among selected zinc levels on zinc-deficient soil both with and without mycorrhizal inoculation were analysed by biplot principal component analysis (PCA), as shown in Fig. 7. This plot revealed that the first two components explained $94.54 \%$ of the variation (PC1 $88.60 \%$, and PC2 5.94\%). The PCA biplot grouped the zinc levels based on maize performance observed for physiological and biochemical variables, showing that the $\mathrm{Zn} 12$ was the best performing situation for improving the maize's overall traits in this experiment. The $\mathrm{Zn} 12$ treatment also helped to improve the nutrient status of the soil. The $\mathrm{Zn} 6$ treatment also provided significant improvement in the measured characteristics. However, the $\mathrm{Zn} 0, \mathrm{Zn} 1.5$ and $\mathrm{Zn} 3$ treatments had a much smaller effect in significantly improving maize growth under zinc deficient soil conditions. 

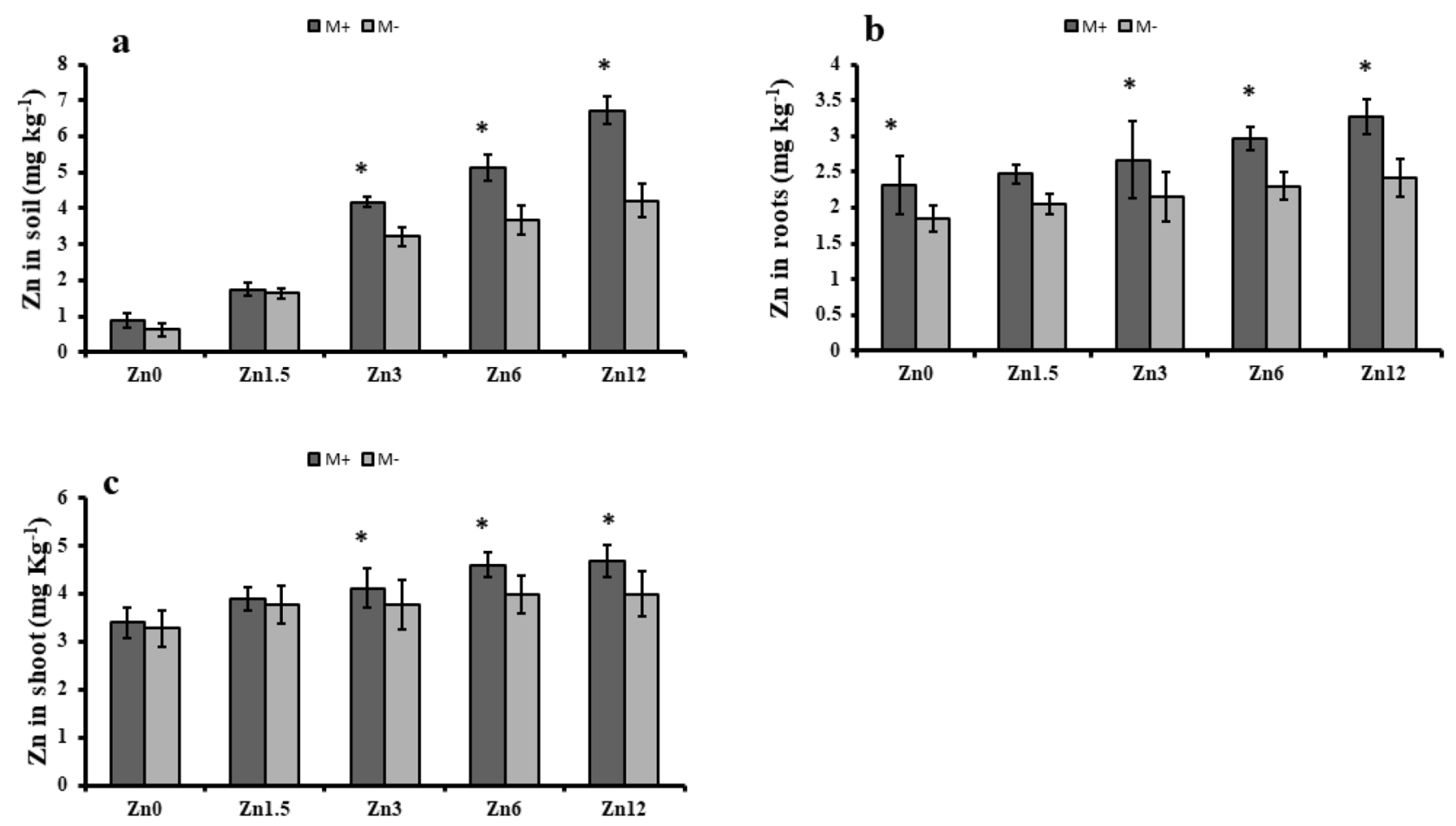

Figure 5. Effect of arbuscular mycorrhizal inoculation on zinc concentration of maize under zinc deficient soil conditions. (a) zinc concentration in soil $\left(\mathrm{mg} \mathrm{kg}^{-1}\right)$ (b) zinc concentration in root $\left(\mathrm{mg} \mathrm{kg}^{-1}\right)$ (c) zinc concentration in shoot $\left(\mathrm{mg} \mathrm{kg}^{-1}\right) . \mathrm{Zn}_{0}$ (control), $\mathrm{Zn}_{1.5}\left(1.5 \mathrm{mg} \mathrm{kg}{ }^{-1}\right), \mathrm{Zn}_{3}\left(3 \mathrm{mg} \mathrm{kg}{ }^{-1}\right), \mathrm{Zn}_{6}\left(6 \mathrm{mg} \mathrm{kg}^{-1}\right), \mathrm{Zn}_{12}$ $\left(12 \mathrm{mg} \mathrm{kg}^{-1}\right)$, inoculated with AMF (M+grey), un-inoculated (M- white). Error bars represent standard error and asterisk $\left(^{*}\right)$ shows significant difference $(p \leq 0.05)$ among treatments $(\mathrm{Zn} \times \mathrm{AMF}$ interaction).
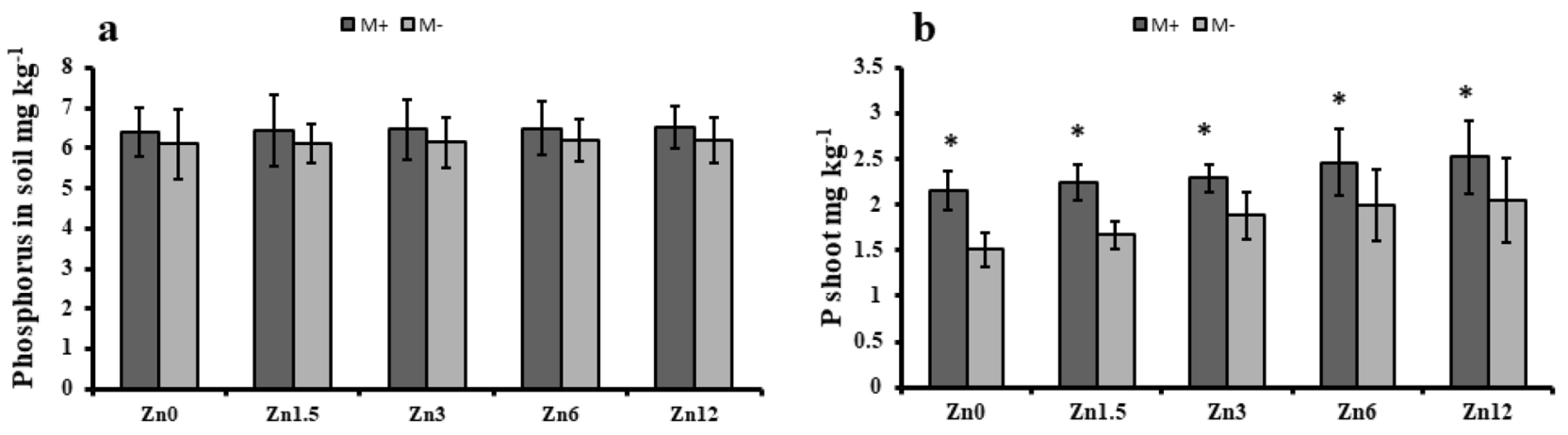

Figure 6. Effect of arbuscular mycorrhizal inoculation on Phosphorus contents of maize under zinc deficient soil conditions. (a) phosphorus concentration in soil $\left(\mathrm{mg} \mathrm{kg}^{-1}\right)$ (b) phosphorus concentration shoot ( $\mathrm{mg} \mathrm{kg}$ $\left.{ }^{-1}\right)$. $\mathrm{Zn}_{0}$ (control), $\mathrm{Zn}_{1.5}\left(1.5 \mathrm{mg} \mathrm{Kg}^{-1}\right), \mathrm{Zn}_{3}\left(3 \mathrm{mg} \mathrm{kg}^{-1}\right), \mathrm{Zn}_{6}\left(6 \mathrm{mg} \mathrm{kg}^{-1}\right), \mathrm{Zn}_{12}\left(12 \mathrm{mg} \mathrm{kg}^{-1}\right)$, inoculated with AMF $\left(\mathrm{M}+\right.$ grey), un-inoculated $\left(\mathrm{M}\right.$ - white). Error bars represent standard error and asterisk $\left.{ }^{*}\right)$ shows significant difference $(p \leq 0.05)$ among treatments $(\mathrm{Zn} \times \mathrm{AMF}$ interaction).

\section{Discussion}

The current study has elaborated the beneficial role of AM colonization compared to non-mycorrhizal plants. Arbuscular mycorrhizal symbiosis alters plants' internal physiological conditions, consequently controlling the opening of stomata, one of the prime sites of photosynthesis ${ }^{40,41}$. A higher photosynthetic rate was attributed to the $\mathrm{Zn} 12(\mathrm{M}+)$ condition compared to non-mycorrhizal plants in this study. Another study supported this result in which it was reported that regulation of abscisic acid and antioxidant enzyme activities are correlated with each other in altering stomatal behaviour ${ }^{42}$. Our results highlight AM symbiosis' importance that can increase the chlorophyll contents of maize in nutrient-deficient soils. Furthermore, mycorrhizal inoculation might enhance the magnesium uptake, which helps develop higher chlorophyll contents similar to what was observed in $\mathrm{Zn} 12$, ultimately resulting in a higher photosynthetic rate ${ }^{43}$. These findings agree with earlier studies' results ${ }^{44,45}$. Presence of AMF protects photosystem II during the photosynthesis that played a significant role in better uptake of nutrients and water. Balance uptake of water Regulate photosynthetic rate through improvement in transpiration 


\begin{tabular}{|c|c|c|c|c|c|c|c|c|c|c|c|c|c|c|c|}
\hline & Photo & Trans & Cond & SOD & CAT & POD & TSP & CHLA & CHLB & TCHL & ZR & ZSH & ZS & PS & PSH \\
\hline Photo & 1 & 0.65 & $0.95^{\star *}$ & $0.81^{*}$ & 0.752 & 0.64 & $0.81^{*}$ & 0.46 & 0.69 & $0.80^{*}$ & 0.77 & 0.777 & $0.84^{*}$ & $0.80^{*}$ & 0.712 \\
\hline Trans & & 1 & 0.78 & $0.92^{*}$ & $0.94^{* *}$ & $0.96^{* *}$ & $0.94^{* \star}$ & $0.80^{*}$ & 0.75 & 0.80 & $0.93^{*}$ & $0.86^{*}$ & $0.84^{*}$ & $0.93^{*}$ & $0.92^{*}$ \\
\hline Cond & & & 1 & $0.82^{*}$ & \begin{tabular}{|l|}
0.79 \\
\end{tabular} & 0.70 & $0.84^{\star}$ & 0.50 & 0.60 & 0.76 & 0.79 & 0.78 & 0.79 & $0.85^{\star}$ & 0.74 \\
\hline SOD & & & & 1 & $0.98^{* *}$ & $0.96^{* *}$ & $0.99^{* *}$ & $0.82^{\star}$ & $0.92^{*}$ & $0.93^{* *}$ & $0.99^{* *}$ & $0.93^{*}$ & $0.97^{* *}$ & $0.99^{* *}$ & $0.96^{* \star}$ \\
\hline CAT & & & & & 1 & $0.96^{* *}$ & $0.98^{* *}$ & $0.88^{*}$ & $0.90^{*}$ & $0.87^{*}$ & $0.98^{* *}$ & $0.88^{\star}$ & $0.93^{* *}$ & $0.98^{* *}$ & $0.94^{* *}$ \\
\hline POD & & & & & & 1 & $0.96^{\star \star}$ & $0.82^{*}$ & $0.88^{*}$ & $0.89^{*}$ & $0.98^{* *}$ & $0.92^{\star}$ & $0.92^{*}$ & $0.96^{* *}$ & $0.98^{\star \star}$ \\
\hline TSP & & & & & & & 1 & 0.79 & $0.89^{\star}$ & $0.93^{* *}$ & $0.99^{* *}$ & $0.94^{* *}$ & $0.97^{* *}$ & $0.99^{* *}$ & $0.97^{* *}$ \\
\hline CHLA & & & & & & & & 1 & 0.80 & 0.60 & 0.79 & 0.58 & 0.71 & 0.79 & 0.73 \\
\hline CHLB & & & & & & & & & 1 & $0.91^{\star}$ & $0.92^{*}$ & $0.85^{\star}$ & $0.95^{* *}$ & $0.90^{*}$ & $0.89^{*}$ \\
\hline TCHL & & & & & & & & & & 1 & $0.95^{* *}$ & $0.98^{* *}$ & $0.98^{* *}$ & $0.94^{* *}$ & $0.95^{* *}$ \\
\hline ZR & & & & & & & & & & & 1 & $0.95^{* *}$ & $0.97^{* *}$ & $0.99^{* *}$ & $0.98^{* \star}$ \\
\hline $\mathrm{ZSH}$ & & & & & & & & & & & & 1 & $0.95^{* *}$ & $0.94^{* *}$ & $0.97^{* *}$ \\
\hline ZS & & & & & & & & & & & & & 1 & $0.97^{* *}$ & $0.95^{* \star}$ \\
\hline PS & & & & & & & & & & & & & & 1 & $0.96^{* *}$ \\
\hline $\mathrm{PSH}$ & & & & & & & & & & & & & & & 1 \\
\hline
\end{tabular}

Table 1. Pearson's correlation coefficients between the variables under zinc-deficient soil conditions. ${ }^{* *}$ Highly significant $(p<0.01)$, ${ }^{*}$ significant $(p<0.05)$. Photo, photosynthetic rate; Trans, transpiration rate; Cond, stomatal conductance; SOD, superoxide dismutase; CAT, catalase; POD, peroxidase; TSP, total soluble protein; CHLA, chlorophyll a; CHLB, chlorophyll b; TCHL, total chlorophyll; ZR, zinc in roots; ZSH, zinc in shoot; ZS, zinc in soil; PS, phosphorus in soil; PSH, phosphorus in shoot.

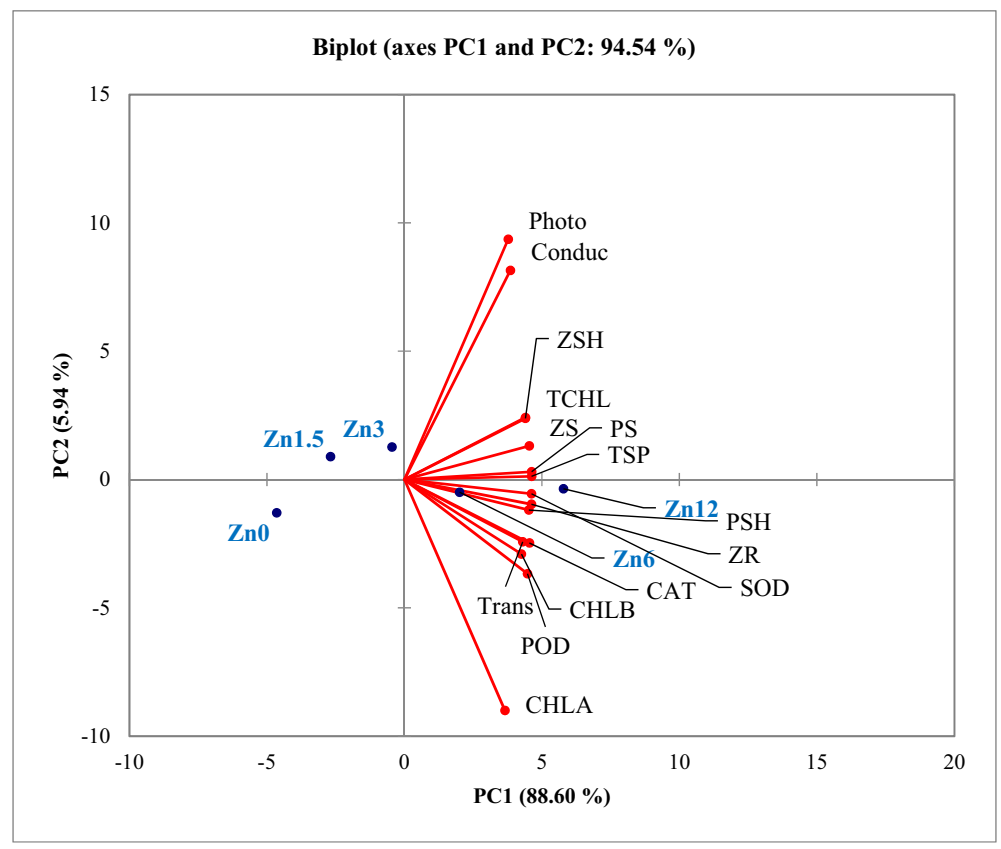

Figure 7. PCA biplot for different zinc levels under zinc deficient soil conditions. PCA biplot is a combination of score plot of zinc levels (represented in blue text) and loading plot of variables (represented by red vectors; black text). Photo, photosynthetic rate; Trans, transpiration rate; Conduc, stomatal conductance; SOD, superoxide dismutase; CAT, catalase; POD, peroxidase; TSP, total soluble protein; CHLA, chlorophyll a; CHLB, chlorophyll b; TCHL, total chlorophyll; ZR, zinc in roots; ZSH, zinc in shoot; ZS, zinc in soil; PS, phosphorus in soil; PSH, phosphorus in shoot.

rate in stomatal conductance. On the other hand, optimum uptake of zinc properly catalyzed the reactions Which facilitate the plants for better growth ${ }^{46-49}$.

Poor uptake of $\mathrm{Zn}$ facilitates the biosynthesis of reactive oxygen species (ROS) during photosynthetic electron transport ${ }^{50}$. However, antioxidants play a critical role in defense system of cells components such as proteins, membrane lipids, SH-containing enzymes, chlorophyll and DNA against ROS. The cysteine, histidine and glutamate or aspartate residues represent the most critical $\mathrm{Zn}$ binding sites in enzymes, DNA-binding proteins (Zn- ${ }^{\oplus}$ nger proteins) and membrane proteins ${ }^{6}$. Improvement in antioxidant enzyme activities were also observed 
in maize tissue samples of current study (Fig. 4). Since SOD is the main ROS scavenging enzyme that converts superoxide ion to $\mathrm{H}_{2} \mathrm{O}_{2}$ (which is also harmful to plant growth), the activity CAT and POD was also shown to be increased in our maize plants. In the present study, plants were exposed to artificial Zn deficient soil conditions, that might result in ROS species' overproduction. However, AM-inoculated maize plants produced higher antioxidant enzyme activity, favouring ROS stress molecule scavenging which diminished the oxidative burst ${ }^{6}$. Both enzyme activities were significantly $(p \leq 0.05)$ higher with AM inoculation than non-inoculated plants. It might be the reason that inoculated plants showed higher SOD activity in this study. Moreover, this enzyme activity also contributed to hyphal transport, which assists in diffusing essential micronutrients necessary for enzyme activities ${ }^{7}$. The AM role observed was supported by an earlier report that the vegetative part (mycelium) of mycorrhizal fungi in the rhizosphere enhance the availability of nutrients to roots.

The maize plant's total soluble protein contents increased in inoculated and non-inoculated plants, although the increased level was highest with inoculated plants with a $\mathrm{Zn}$ dose of $6 \mathrm{mg} \mathrm{kg}^{-1}$ of soil. Our results regarding the increase in soluble proteins agree with previous reports ${ }^{7}$. In a separate study, mycorrhizal inoculation resulted in a soluble protein increase of 2 -sixfold in clover plants ${ }^{51}$.

The higher availability of $\mathrm{Zn}$ in the soil might be due to the AM role in synthesizing amino acids (tryptophan and asparagine). Therefore, the current study showed that higher levels of $\mathrm{Zn}$ resulted in higher $\mathrm{Zn}$ availability in soil. Likewise, it allowed the plants a higher level of Zn uptake. Our results regarding higher zinc accumulation were consistent with the results of the earlier report of Marques et al. ${ }^{52}$ and are also confirmed by another study on maize, concluding that mycorrhizal inoculation renders a positive role in the accumulation of $\mathrm{Zn}$ under zinc-deficient soil ${ }^{53}$.

Phosphorus is a relatively immobile nutrient in soil yet its concentration in the soil increased with the elevated levels of $\mathrm{Zn}$ fertilization irrespective of mycorrhizal inoculation. However, in the case of $\mathrm{Zn}$ uptake in shoots, contrary results showed by inoculated maize plants. It might be the reason that $\mathrm{M}+$ assisted maize plants in the absorption of phosphorus by the roots. Numerous studies have reported AM positive role in phosphorus accumulation $^{28,54}$. Moreover, increasing the level of $\mathrm{Zn}$ increased the root surface area of the plant with mycorrhizal colonization. It also secreted the glomalin protein that solubilizes the fixed phosphorus, resulting in a higher concentration of phosphorus in the soil.

\section{Conclusions}

The current study showed the beneficial role of arbuscular mycorrhizal inoculation for maize growth on zincdeficient soil. It improved the maize's gaseous exchange traits, such as a higher photosynthetic rate and a higher zinc application level. The chlorophyll contents also improved with higher zinc fertilization and inoculation of maize plants. These favourable maize physiology changes were solely due to a higher nutrient availability under deficient soil conditions. Inoculated plants also showed a higher accumulation of nutrients and their availability in soil.

Received: 20 March 2021; Accepted: 30 August 2021

Published online: 16 September 2021

\section{References}

1. Alloway, B. J. Soil factors associated with zinc deficiency in crops and humans. Environ. Geochem. Health 31, 537-548 (2009).

2. Bibi, F. et al. Effect of various application rates of phosphorus combined with different zinc rates and time of zinc application on phytic acid concentration and zinc bioavailability in wheat. Agric. Nat. Resour. 54, 265-272 (2020).

3. Tahir, F. A., Ahamad, N., Rasheed, M. K. \& Danish, S. Effect of various application rate of zinc fertilizer with and without fruit waste biochar on the growth and Zn uptake in maize. Int. J. Biosci. 13, 159-166 (2018).

4. Rafique, E., Rashid, A., Ryan, J. \& Bhatti, A. U. Zinc deficiency in rainfed wheat in Pakistan: Magnitude, spatial variability, management, and plant analysis diagnostic norms. Commun. Soil Sci. Plant Anal. 37, 181-197 (2006).

5. Duc, N. H., Csintalan, Z. \& Posta, K. Arbuscular mycorrhizal fungi mitigate negative effects of combined drought and heat stress on tomato plants. Plant Physiol. Biochem. 132, 297-307 (2018).

6. Cakmak, I. Tansley Review No. 111 Possible roles of zinc in protecting plant cells from damage by reactive oxygen species. New Phytol. 146, 185-205 (2000).

7. Subramanian, K. S., Tenshia, J. S. V., Jayalakshmi, K. \& Ramachandran, V. Antioxidant enzyme activities in arbuscular mycorrhizal (Glomus intraradices) fungus inoculated and non-inoculated maize plants under Zinc Deficiency. Indian J. Microbiol. 51, 37-43 (2011).

8. Aslanpour, M., Baneh, H. D., Tehranifar, A. \& Shoor, M. Effect of mycorrhizal fungi on macronutrients and micronutrients in the white seedless grape roots under the drought conditions. Int. Trans. J. Eng. Manag. Appl. Sci. Technol. 10, 397-408 (2019).

9. Wahid, F. et al. Sustainable management with mycorrhizae and phosphate solubilizing bacteria for enhanced phosphorus uptake in calcareous soils. Agriculture 10, 334 (2020).

10. Smith, S. E., Smith, F. A. \& Jakobsen, I. Mycorrhizal fungi can dominate phosphate supply to plants irrespective of growth responses. Plant Physiol. 133, 16-20 (2003).

11. Latef, A. A. H. A. \& Chaoxing, H. Arbuscular mycorrhizal influence on growth, photosynthetic pigments, osmotic adjustment and oxidative stress in tomato plants subjected to low temperature stress. Acta Physiol. Plant. 33, 1217-1225 (2011).

12. Alizadeh, O., Zare, M. \& Nasr, A. H. Evaluation effect of mycorrhiza inoculate under drought stress condition on grain yield of sorghum (Sorghum bicolor). Adv. Environ. Biol. 5, 2361-2364 (2011).

13. Cavagnaro, T. R. et al. Arbuscular mycorrhizas, microbial communities, nutrient availability, and soil aggregates in organic tomato production. Plant Soil 282, 209-225 (2006).

14. Nunes, J. L. da S., de Souza, P. V. D., Marodin, G. A. B. \& Fachinello, J. C. Effect of arbuscular mycorrhizal fungi and indolebutyric acid interaction on vegetative growth of 'Aldrighi' peach rootstock seedlings. Cienc. e Agrotecnologia 34, 80-86 (2010).

15. Davies, F. T., Puryear, J. D., Newton, R. J., Egilla, J. N. \& Saraiva Grossi, J. A. Mycorrhizal fungi enhance accumulation and tolerance of chromium in sunflower (Helianthus annuus). J. Plant Physiol. 158, 777-786 (2001).

16. Kucey, R. M. N., Janzen, H. H. \& Leggett, M. E. Microbially mediated increases in plant-available phosphorus. Adv. Agron. 42, 199-228 (1989). 
17. Senovilla, M. et al. MtCOPT2 is a Cu+ transporter specifically expressed in Medicago truncatula mycorrhizal roots. Mycorrhiza 30, 781-788 (2020).

18. Coccina, A. et al. The mycorrhizal pathway of zinc uptake contributes to zinc accumulation in barley and wheat grain. BMC Plant Biol. 19, (2019).

19. Tu, J. L., Liu, X. M. \& Xiao, J. X. Effects of arbuscular mycorrhizal inoculation on osmoregulation and antioxidant responses of blueberry plants. Bangladesh J. Bot. 48, 641-647 (2019).

20. Sato, T. et al. Secretion of acid phosphatase from extraradical hyphae of the arbuscular mycorrhizal fungus Rhizophagus clarus is regulated in response to phosphate availability. Mycorrhiza 29, 599-605 (2019).

21. Subramanian, K. S., Bharathi, C. \& Jegan, A. Response of maize to mycorrhizal colonization at varying levels of zinc and phosphorus. Biol. Fertil. Soils 45, 133-144 (2008).

22. Walkley, A. \& Black, I. A. An examination of the degtjareff method for determining soil organic matter, and a proposed modification of the chromic acid titration method. Soil Sci. 37, 29-38 (1934).

23. Olsen, S., Cole, C., Watanabe, F. \& Dean, L. Estimation of available phosphorus in soils by extraction with sodium bicarbonate. (United States Department of Agriculture, 1954).

24. Pratt, P. F. Potassium. in Methods of Soil Analysis: Part 2 Chemical and Microbiological Properties, 9.2 (ed. Norman, A. G.) 1022-1030 (John Wiley \& Sons, Ltd, 1965). https://doi.org/10.2134/agronmonogr9.2.c20.

25. Lindsay, W. L. \& Norvell, W. A. A DTPA soil test for zinc, iron, manganese and copper. Soil Sci. Soc. Am. J. 42, 421-428 (1978).

26. Martin, F., Winspear, M. J., MacFarlane, J. D. \& Oaks, A. Effect of methionine sulfoximine on the accumulation of ammonia in $\mathrm{C}_{3}$ and $\mathrm{C}_{4}$ leaves. Plant Physiol. 71, 177-181 (1983).

27. Ohno, T. \& Zibilske, L. M. Determination of low concentrations of phosphorus in soil extracts using malachite green. Soil Sci. Soc. Am. J. 55, 892-895 (1991).

28. Ryan, M. H., McInerney, J. K., Record, I. R. \& Angus, J. F. Zinc bioavailability in wheat grain in relation to phosphorus fertiliser, crop sequence and mycorrhizal fungi. J. Sci. Food Agric. 88, 1208-1216 (2008).

29. Thomas, G. W. Soil pH and soil acidity. In Methods of Soil Analysis, Part 3: Chemical Methods vol. 5 475-490 (John Wiley \& Sons, 1996).

30. Rhoades, J. D. Salinity: Electrical Conductivity and Total Dissolved Solids. in Methods of Soil Analysis, Part 3, Chemical Methods (eds. D.L. Sparks et al.) vol. 5 417-435 (Soil Science Society of America, 1996).

31. Danish, S. \& Zafar-ul-Hye, M. Co-application of ACC-deaminase producing PGPR and timber-waste biochar improves pigments formation, growth and yield of wheat under drought stress. Sci. Rep. 9, 5999 (2019).

32. Arnon, D. I. Copper enzymes in isolated chloroplasts Polyphenoloxidase in Beta vulgaris. Plant Physiol. 24, 1-15 (1949).

33. Giannopolitis, C. N. \& Ries, S. K. Superoxide dismutases: I Occurrence in higher plants. Plant Physiol. 59, 309-314 (1977).

34. Chance, B. \& Maehly, A. C. Assay of catalases and peroxidases. Methods Enzymol. 2, 764-775 (1955).

35. Sambrook, J. \& Russell, D. W. In vitro mutagenesis using double-stranded DNA templates: selection of mutants with DpnI. Cold Spring Harb. Protoc. 2, 13-19 (2006).

36. Bradford, M. M. A rapid and sensitive method for the quantitation of microgram quantities of protein using the principle of protein dye binding. Anal. Biochem. 72, 248-254 (1976).

37. Phillips, J. M. \& Hayman, D. S. Improved procedures for clearing roots and staining parasitic and vesicular-arbuscular mycorrhizal fungi for rapid assessment of infection. Trans. Br. Mycol. Soc. 55, 158-IN18 (1970).

38. Vierheilig, H., Coughlan, A. P., Wyss, U. \& Piché, Y. Ink and vinegar, a simple staining technique for arbuscular-mycorrhizal fungi. Appl. Environ. Microbiol. 64, 5004-5007 (1998).

39. Steel, R. G., Torrie, J. H. \& Dickey, D. A. Principles and Procedures of Statistics: A Biometrical Approach. (McGraw Hill Book International Co., 1997).

40. Shahzad, S., Khan, M. Y., Zahir, Z. A., Asghar, H. N. \& Chaudhry, U. K. Comparative effectiveness of different carriers to improve the efficacy. Pakistan J. Bot. 49, 1523-1530 (2017).

41. Lawson, T. Guard cell photosynthesis and stomatal function. New Phytol. 181, 13-34 (2009).

42. Goicoechea, N., Antolín, M. C. \& Sánchez-Díaz, M. Gas exchange is related to the hormone balance in mycorrhizal or nitrogenfixing alfalfa subjected to drought. Physiol. Plant. 100, 989-997 (1997).

43. Mathur, N. \& Vyas, A. Biochemical changes in Ziziphus xylopyrus by VA mycorrhizae. Bot. Bull. Acad. Sin. 37, 209-212 (1996).

44. Sannazzaro, A. I., Ruiz, O. A., Albertó, E. O. \& Menéndez, A. B. Alleviation of salt stress in Lotus glaber by Glomus intraradices. Plant Soil 285, 279-287 (2006).

45. Colla, G. et al. Alleviation of salt stress by arbuscular mycorrhizal in zucchini plants grown at low and high phosphorus concentration. Biol. Fertil. Soils 44, 501-509 (2008).

46. Yang, Y. et al. The combined effects of arbuscular mycorrhizal fungi (AMF) and lead ( $\mathrm{Pb}$ ) stress on $\mathrm{Pb}$ accumulation, plant growth parameters, photosynthesis, and antioxidant enzymes in Robinia pseudoacacia L. PLoS One 10, e0145726 (2015).

47. Lu, C. \& Vonshak, A. Effects of salinity stress on photosystem II function in cyanobacterial Spirulina platensis cells. Physiol. Plant. 114, 405-413 (2002).

48. Chaves, M. M., Flexas, J. \& Pinheiro, C. Photosynthesis under drought and salt stress: regulation mechanisms from whole plant to cell. Ann. Bot. 103, 551-560 (2009).

49. Toler, H. D., Morton, J. B. \& Cumming, J. R. Growth and metal accumulation of mycorrhizal sorghum exposed to elevated copper and zinc. Water. Air. Soil Pollut. 164, 155-172 (2005).

50. Marschner, H. \& Cakmak, I. High Light Intensity Enhances Chlorosis and Necrosis in Leaves of Zinc, Potassium, and Magnesium Deficient Bean (Phaseolus vulgaris) Plants. J. Plant Physiol. 134, 308-315 (1989).

51. Arines, J., Palma, J. M. \& Viarino, A. Comparison of protein patterns in non-mycorrhizal and vesicular-arbuscular mycorrhizal roots of red clover. New Phytol. 123, 763-768 (1993).

52. Marques, A. P. G. C., Oliveira, R. S., Rangel, A. O. S. S. \& Castro, P. M. L. Application of manure and compost to contaminated soils and its effect on zinc accumulation by Solanum nigrum inoculated with arbuscular mycorrhizal fungi. Environ. Pollut. 151, 608-620 (2008).

53. Zhang, W. et al. Zinc uptake by roots and accumulation in maize plants as affected by phosphorus application and arbuscular mycorrhizal colonization. Plant Soil 413, 59-71 (2017).

54. Cavagnaro, T. R. The role of arbuscular mycorrhizas in improving plant zinc nutrition under low soil zinc concentrations: a review. Plant Soil 304, 315-325 (2008).

\section{Acknowledgements}

We acknowledge Directorate of Research Bahauddin Zakariya University Multan, Pakistan for facilitating us for research. The study was also supported by Researchers Supporting Project number (RSP-2021/257), King Saud University, Riyadh, Saudi Arabia. 


\section{Author contributions}

Conceptualization, A.S.; M.A.A.; N.A.; methodology, A.S.; M.A.A.; N.A.; software, A.S.; M.A.A.; N.A.; validation, A.S.; M.A.A.; N.A.; formal analysis, A.S.; M.A.A.; N.A.; investigation, A.S.; M.A.A.; N.A.; resources, A.S.; M.A.A.; N.A.; data curation, A.S.; M.A.A.; N.A.; writing-original draft preparation, S.D.; S.F.; R.D.; B.R.G.; writing—review and editing, S.D.; S.F.; R.D.; B.R.G.; M.J.A.; O.N.; M.H.u.R.; supervision, M.A.A.

\section{Funding}

We are thankful to Researchers Supporting Project number (RSP-2021/257), King Saud University, Riyadh, Saudi Arabia for their financial support.

\section{Competing interests}

The authors declare no competing interests.

\section{Additional information}

Correspondence and requests for materials should be addressed to M.A.A. or S.D.

Reprints and permissions information is available at www.nature.com/reprints.

Publisher's note Springer Nature remains neutral with regard to jurisdictional claims in published maps and institutional affiliations.

(c) (i) Open Access This article is licensed under a Creative Commons Attribution 4.0 International License, which permits use, sharing, adaptation, distribution and reproduction in any medium or format, as long as you give appropriate credit to the original author(s) and the source, provide a link to the Creative Commons licence, and indicate if changes were made. The images or other third party material in this article are included in the article's Creative Commons licence, unless indicated otherwise in a credit line to the material. If material is not included in the article's Creative Commons licence and your intended use is not permitted by statutory regulation or exceeds the permitted use, you will need to obtain permission directly from the copyright holder. To view a copy of this licence, visit http://creativecommons.org/licenses/by/4.0/.

(C) The Author(s) 2021 